\title{
A comparative study of laparoscopic partial hepatectomy by clamp-crush and ultrasurgical techniques in rams
}

\author{
A.A. Ajeel, M.J. Eesa, R.N. Al-Asadi and M.A. Alkhilani \\ Department of Surgery and Obstetrics, University of Baghdad, Baghdad, Iraq
}

\begin{abstract}
The present study was designed to evaluate the feasibility and safety of laparoscopic partial hepatectomy via two techniques in rams. Twenty-four adult local breed rams were used, which divided randomly and equally into two groups. All animals subjected to laparoscopic partial hepatectomy. operations were performed under the effect of general anesthesia by using $5 \%$ thiopental sodium at a dose rate of $15 \mathrm{mg} / \mathrm{kg} \mathrm{B}$.W., intravenously and maintenance was done by inhalation (halothane) (2- 2.5\%). Animals placed in a reverse Trendelenburg $\left(30^{\circ}\right)$ and left lateral position. Pneumoperitoneum was achieved under $(10-12 \mathrm{mmHg})$. Four $(10 \mathrm{~mm})$ ports were made on ventral abdominal wall. Liver parenchyma was controlled with modified liver clamp. In first group, partial hepatectomy was done by Clamp-crush forceps. While in second group, Ultra- surgical device was used. Following operations, certain parameters such as rectal temperature, respiratory rate, heart rate, food intake, and secondary health problemes had been recorded. Also the operative and resection times and blood loss were estimated. Liver enzymes (alinine transaminase, aspartate transaminase, alkaline phosphate, total serum bilirubin and total serum proteins were measured. Histopathological examination of liver biobsies was performed at $3^{\text {rd }}, 7^{\text {th }}, 15^{\text {th }}$ days and four months post-surgery. The main intra-operative complication was the bleeding. Result indicated that the vital parameters were within the normal rang. Shorter operative and resection times were noticed in second group when compared with first group. There were no significant differences in the mean values of blood loss in both groups. Also no bile collection were seen in the abdominal cavity or subphrinic region during the exploratory laparoscopy at $(3,7$, and 15 days) and four months post-surgery. There were no significant differences in the mean values of the liver function test (liver enzymes) in two groups. Macroscopic examination revealed the presence of adhestion between liver and adjcent structures with varing degree. The normal structures of the liver which consist of hepatocytes and central vein returned within 4 months post operations in second group. We can conclude that the laparoscopic partial hepatectomy in rams can be safely performed under Ultrasurgical technique with a modified liver clamp which reflected minor secondary complications and early liver regeneration.
\end{abstract}

Keywords: Laparoscopic Partial Hepatectomy; Clamp-crush; Ultrasurgical; Rams.

Available online at http://www.vetmedmosul.org/ijvs

\section{دراسة مقارنة لاستثئصال ألكبد الجزئي" منظاريا" بطريقتي Clamp-crush و في الاكباش \\ علي عباس عجيل، محمد جواد عيسى، راهي ناهي الاسدي و ماجد عبد الرحمن غضبان فرع الجر احة و التوليد، كلية الطب البيطري، جامعة بغداد، بغداد، العراق}

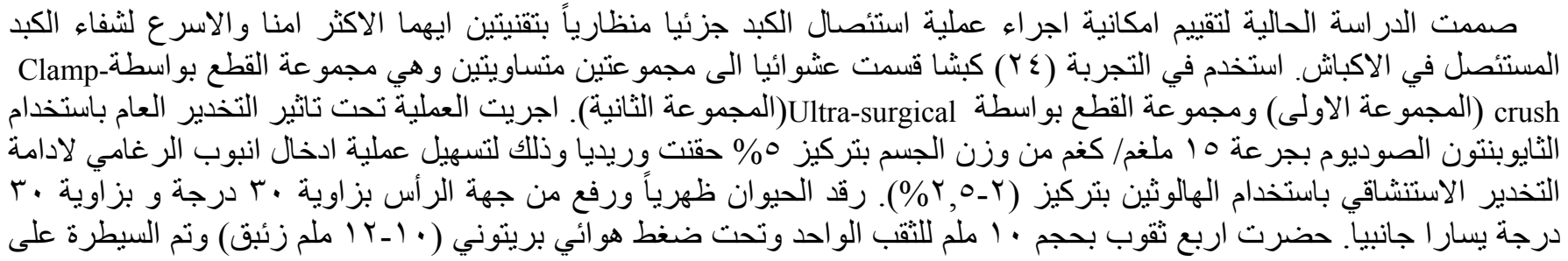




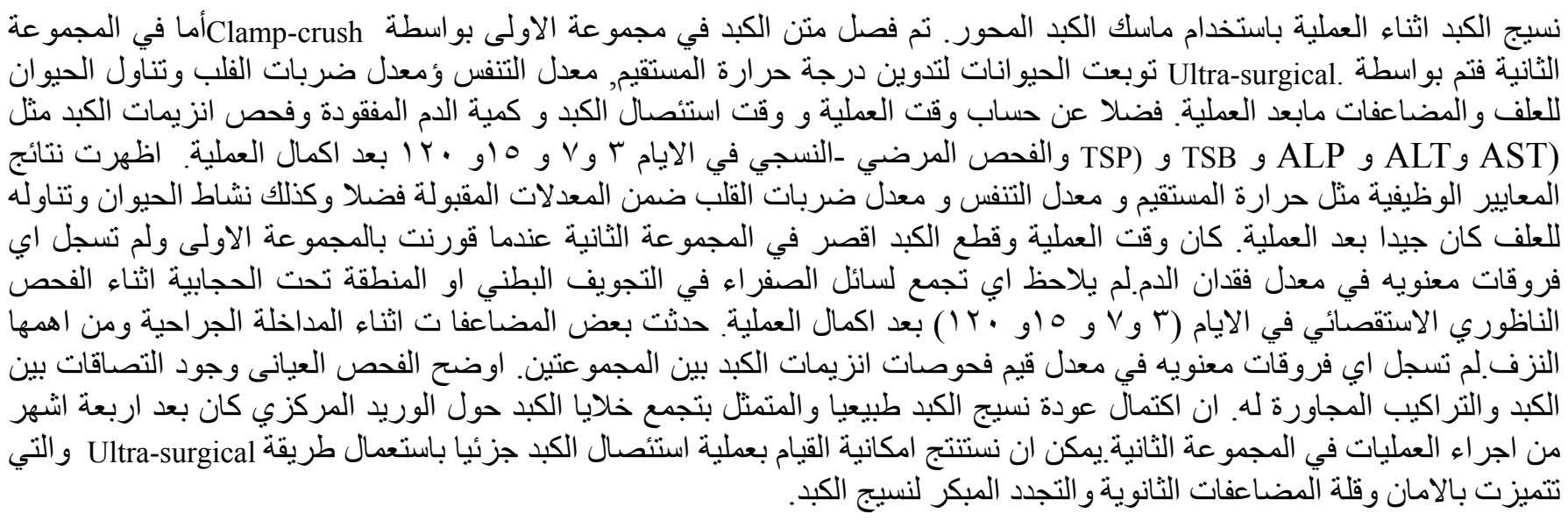

\section{Introduction}

Liver resection was first described centuries ago, but until the half of the $20^{\text {th }}$ century, the majority of such resections were performed for management of either injuries or infections. Today, these procedures are performed not only for treatment of acute emergencies such as traumatic injuries and for curative therapy of a variety of benign and malignant hepatic lesions (1). Laparoscopic hepatic resection has been greatly facilitated by several recent technology advances, including laparoscopic staplers and ultrasonic dissectors which can be used for ligation of the hepatic vasculature and transection of liver parenchyma (2). Several studies have been performed, but with different end points, techniques and study designs making the results difficult to interpret. The optimal method for transecting liver parenchyma preferably one that does not necessitate vascular inflow control, has not been established and a variety of techniques are in use (3). The aim of this study was to compare the safety and efficacy of the two surgical techniques for the laparoscopic partial liver resection represented by (clamp-crush and ultra surgical) in rams without using vascular inflow occlusion, based on clinical follow-up, liver function test, feasibility of techniques and pathological findings.

\section{Materials and methods}

Twenty four adult local breed rams, ages were (2.5- 4) years and weighing (40-50) $\mathrm{kg}$. Rams were randomly and equally allocated into two group. In first group, animals subjected to partial hepatectomies by laparoscopic clampcrush technique. While in second group, hepatectomies were performed by laparoscopic ultrasurgical technique (Figure 1) (Harmonic scalpel was used (Ethicon End surgery, ING. Germany). Food withheld for (36- 48 hrs) and water for $(12 \mathrm{hrs})$ prior to surgery. The ventral abdominal region was prepard aseptically for surgical operation from the xyphoid cartilage to the pubis and laterally as far as the flanks. Preoperative blood samples (zero time) were collected for liver function tests. All operations were performed under the effect of general anesthesia through the induction with $5 \%$ thiopental sodium at a dose $15 \mathrm{mg} / \mathrm{kg} \mathrm{B.W}$, and maintenance of anesthesia with halothane (2-2.5\%) (4). Animals placed in a reverse Trendelenburg $30^{\circ}$ and $30^{\circ}$ left lateral decubital positions with the surgeon standing on the left side.

Four ports $(10 \mathrm{~mm})$ were made, the first port was at the umbilicus for telescope, the second port, right to the midline for the modified liver clamp, the third port, left to the midline for the (clamp-crush and ultrasonic device) and the fourth port at lower right subcostal region for suctionirrigation and finally enlarged for biopsies extraction (Figures 2 and 3).

Direct trocar entry technique was used, a vertical cutaneous incision $1 \mathrm{~cm}$ length was made to accommodate the primary cannula without trocar. Pneumoperitoneum was obtained at $(10-12 \mathrm{~mm} \mathrm{Hg})$ with a rate flow of 3.5 liters/minute. A modified liver clamp was used for grasping the liver parenchyma during resection. This clamp introduced through $2^{\text {nd }}$ port; it could be introduced also through $4^{\text {th }}$ port. The length of the transected parenchyma was equal to the length of clamp jaws $(10 \mathrm{~cm})$. In clampcrush technique, a straight crush forceps was used to fracture and divide small section of the parenchyma before securing and severing the supposedly spared vessels (Figure 4).Titanium clips have been used for securing the separated vessels (Figure 5), then severed with scissors.

In ultrasurgical technique, liver parenchyma was coagulated and transected by using $5 \mathrm{~mm}$ hock-spatula blade through coagulation and cutting mode at levels of (3-5) (Figures 6 and 7). Ten $\mathrm{mm}$ grasper was used at $2^{\text {nd }}$ or $4^{\text {th }}$ port for grasping and extraction the liver biopsies. Enlarged the extraction site $(2.5 \mathrm{~cm})$ for extraction the biopsies longitudinally from this site. Temporarily sealed to the site of extraction and pneumoperitoneum re-established to 
inspect remaining liver (raw surface) and performed additional hemeostasis if needed. All ports were removed under direct vision, and the pneumoperitoneum was deflated. The extraction site was irrigated with normal saline and closed with one layer simple continuous suturing by chromic cut gut (size 1). The skin closed with interrupted horizontal mattress suturing by silk (size 2). Penicillin - streptomycin I.M., in a dose of $20.000 \mathrm{IU} / \mathrm{kg}$ B.W. and $10 \mathrm{mg} / \mathrm{kg} \mathrm{B.W.,} \mathrm{respectively} \mathrm{was} \mathrm{adminstered} \mathrm{for}$ five conscuative days.Slik stitches were removed 10 days post-surgery. Clinical examination including temperature, respiratory rate and heart rate were monitored during the first week following surgery. Operative time started from first skin incision (umbilical incision) to the end of skin suturing. Resection time (RT), started at the beginning of parenchymal transection till completing it were recorded.

The volume of intra- operative blood loss was collected in the container of suction irrigation machine. The normal saline which was used in irrigation, excluded from total volume mixture in the suction container when intra operative blood loss measuered. Exploratory laparoscopy of the abdominal cavity was done for evaluation of adhesions, bile leakage detection and harvesting liver biopsies, and performed via 2-3 ports under sedation with xylazine in a dose of $0.05 \mathrm{mg} / \mathrm{kg} \mathrm{B} . W$., then local anesthesia repersented by lidocaine hydrochloride $2 \%(5 \mathrm{ml})$ was used by subcutaneous infiltration at the site of ports. Adhesions were evaluated laparoscopically quantitatively and qualitatively at 60 days postoperatively. Evaluation was depended upon two adhesions grading schemes: Quantitative evaluation: Multiple Sites Adhesions Scheme (MSAS) modified from (6). Qualitative evaluation: Adhesive Tissue Tenacity Schemes (ATTS) was used (7). The presence of bile leakage in the abdominal cavity on $3^{\text {rd }}$ and $7^{\text {th }}$ days and 4 months postoperatively was evaluated by exploratory laparoscopy at the same time of liver biopsies.

The blood samples were collected by vacationer tube with adapter, preoperatively (zero time) and at 1, 3,5,7 and 9 days postoperatively. The sera put in separated labeled tubes and kept at $-20 \mathrm{C}^{0}$ until performed liver function test by using diagnostic kits and spectrophotometer.

\section{Alkaline Phosphatase (ALP): \\ Calculation $=\frac{\text { ODseresum anmple-ODserum blank }}{\text { OD standerd }} \times \mathbf{n}$}

Kind and king U/100ml: $\mathrm{n}=20$. U/L: $\mathrm{n}=142$

Total bilirubin (TB):

Calculation $=\frac{\text { A sample }- \text { A blank }}{\text { A call }} \times \mathbf{C c a l}=\mathbf{m g} / \mathbf{d}$ l

Total protein (TP):

Calculation $=\frac{\text { OD sample }}{\text { OD standerd }} \times$ standard concentration $=\mathrm{g} / \mathrm{dl}$
Liver biopsies were harvested laparoscopically at $3^{\text {rd }}$, $7^{\text {th }}, 15^{\text {th }}$, days and $4^{\text {th }}$ months postoperatively. The prepared slids were stained with Hematoxyline and Eosin dye (8) and examined under light microscope.

\section{Statistical Analysis}

The data were expressed as Means \pm S.E. Two ways Analysis of Variance (ANOVA) continued with Least Significant Differences (L.S.D.) were used and $\mathrm{P}<0.05$ was considered to be significant. Statistical Package for Social Sciences (SPSS) was used (9)

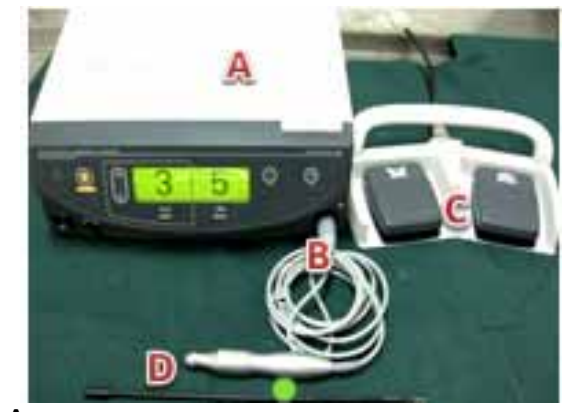

Fig.1: Ultrasonic device: Generator (A), Hand piece (B), Foot switches (C), Ultrasonic blade (D).

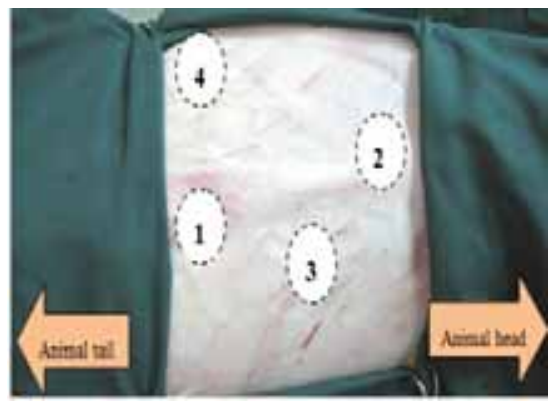

Fig. 2: Ports sites for laparoscopic instruments.

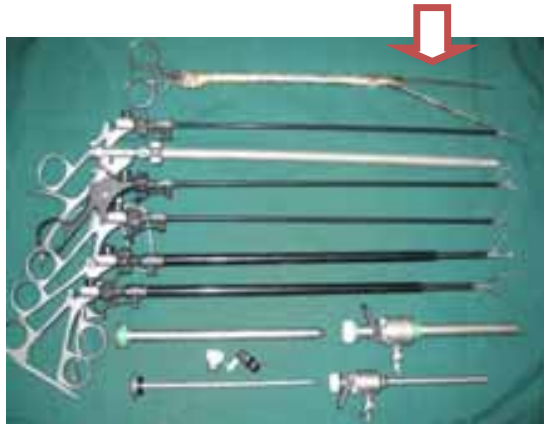

Fig .3: Shows laparoscopic instruments, modified liver clamp. ( - ). 


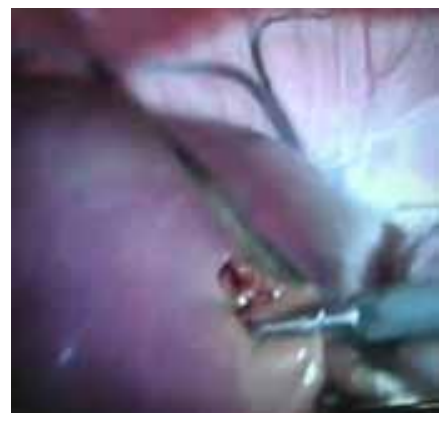

Fig. 4: Straight crush forceps to fracture and divide the paranchyma.

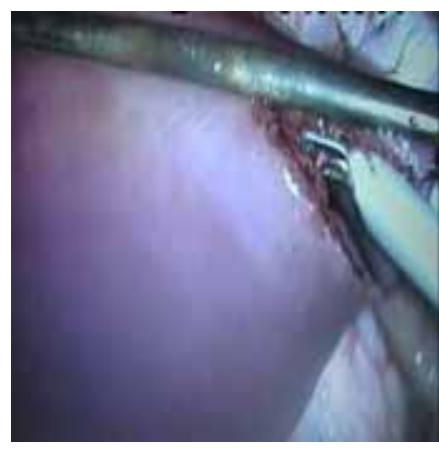

Fig. 5: Clip applicator used to secure the vessel.

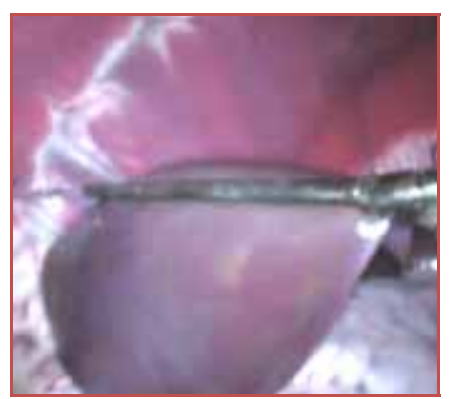

Fig. 6: Liver parenchyma controlled with modified liver clamp.

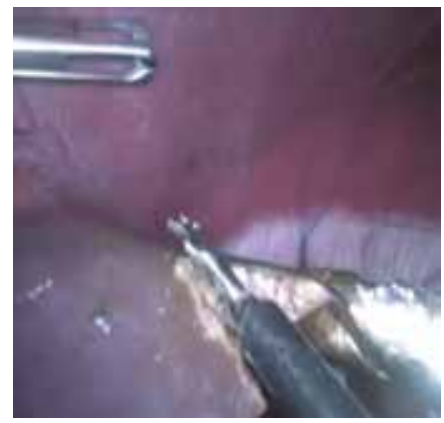

Fig. 7: Ultrasurgical technque for parenchyma Resection.

\section{Results}

In the present study, the vital parameters which included rectal temperature, respiratory rate and heart rate were within the acceptable limits post operatively in all treatment animals, The animal's activity which was represented by animal posture, motion and alert to the surrounding and appetite were not altered. However there were three animals in first group have normal appetite but limited activity during third day postoperatively; Liver clamp is important to minimized the risk of intra- operative liver bleeding and reduce or prevent the risk of gas embolism, facilitated the liver parenchyma control and manipulation during resection.

There were significant differences $\mathrm{P}<0.05$ in mean values of the operative time between the two groups ( $68.3 \pm$ 4.2 and $57.1 \pm 1.8)$ respectively. While the resection time was $(35.5 \pm 1.3)$ in the first group and $(28.8 \pm 1.8)$ in the second group, this means that both parameters were shorter in second group when compared with the first groups. There was no significant differences $(\mathrm{P}>0.05)$ in intraoperative blood loss in two groups (Table 1).

Results of ALT and AST were listed in (Table 4). The values of ALT in second group, showed significant increased $\mathrm{P}<0.05$ of this enzyem when compared with first group at zero, $1^{\text {st }}, 3^{\text {rd }}$ and $7^{\text {th }}$ days postoperatively. Also there were no significant differences among different periods within each group $(\mathrm{P}>0.05)$. Result of AST, showed significant increased $(\mathrm{P}<0.05)$ in mean levels of this enzyme at $1^{\text {st }}, 3^{\text {rd }}$ and $5^{\text {th }}$ days postoperatively in both groups. The values of ALP (Table 5) showed no significant differences among different periods in both groups. Also TSB values (Table 6), showed no significant differences (P $>0.05$ ) between both groups and among various periods. The TSP results (Table 7), showed declined in mean values of TSP in the two groups at $3^{\text {rd }}, 5^{\text {th }}, 7^{\text {th }}$ and $9^{\text {th }}$ days postoperatively but it was not significant.

Table 1: Shows the operative time, resection time and blood loss.

\begin{tabular}{lccccc}
\hline \multirow{2}{*}{ Groups } & \multicolumn{5}{c}{ Number of animals for each grade } \\
\cline { 2 - 6 } & Grade & Grade & Grade & Grade & Grade \\
& 0 & 1 & 2 & 3 & 4 \\
\hline First & 0 & 2 & 3 & 4 & 3 \\
Second & 0 & 6 & 4 & 2 & 0 \\
\hline LSD $=8.9$ for OT. LSD $=3.8$ for RT. LSD $=61.1$ for \\
Blood loss, Different & small letters & vertically & refers to \\
significant differences $\mathrm{P}<0.05$.
\end{tabular}

Macroscopical findings

Some animals had intra-abdominal adhesions of various degrees between liver and multiple organs and abdominal 
wall (Tables 2, 3 and Figures 8,9). There was no bile collection in the abdominal cavity or subphrenic region during the exploratory laparoscopy at $3^{\text {rd }}, 7^{\text {th }} 15^{\text {th }}$ days and four months postoperatively.

\section{Microscopical findings}

The histopathological examination of the liver biobsies were as followings: In the first group and at three days postoperation, showed widely dilated sinusoids and vacuolar degeneration of hepatocytes adjacent the resected area (Figs. 10). While in second group, and at the same period there was necrotic area with few neutrophils infiltration, also hepatocytes showed vacuolar degeneration with dilated sinusoids (Fig. 11). At seven days, first group, reflected mild regeneration of hepatocytes (Fig. 12). In contrast, second group, exhibeted extensive regenerative activity in hepatocytes adjacent to the resected part which form nodular structure without central vein and sinusoids extended into the resected part (Fig.13). At fifteen days, first group, revieled mild regenerative activity which characterized by hyperchromatin of their nuclei (Fig. 14). Pictures of second group and at the same period reflected normal structure of the hepatocytes in area far away from resected area with dark basophilic nuclei and some cells had more nuclei (Fig.15). The pathognomonic features at four months postoperation in first group, reflected retention of the liver to its normal structure which consist from hepatocytes cord around central vein (Fig.16). In contrast second group, showed normal hepatic architectures which represented by normal lobules, central vein and sinusoids (Fig. 17).

Table 2: Shows Multiple Sites Adhesions Schemes (MSAS).

\begin{tabular}{lccc}
\hline Groups & $\begin{array}{c}\text { Operative } \\
\text { Time } / \text { minutes }\end{array}$ & $\begin{array}{c}\text { Resection } \\
\text { Time } / \text { minutes }\end{array}$ & Blood loss $/ \mathrm{ml}$ \\
\hline First & $68.3 \pm 2.4 \mathrm{~b}$ & $35.5 \pm 1.3 \mathrm{~b}$ & $166.7 \pm 23.1 \mathrm{~b}$ \\
Second & $57.1 \pm 1.8 \mathrm{c}$ & $28.8 \pm 1.1 \mathrm{c}$ & $175 \pm 16.7 \mathrm{~b}$ \\
\hline
\end{tabular}

Table 3: Shows Adhesive Tissue Tenacity Schemes (ATTS).

\begin{tabular}{lccccc}
\hline \multirow{2}{*}{ Groups } & \multicolumn{5}{c}{ Number of animals for each grade } \\
\cline { 2 - 6 } & Grade & Grade & Grade & Grade & Grade \\
& 0 & 1 & 2 & 3 & 4 \\
\hline First & 0 & 0 & 2 & 4 & 6 \\
Second & 0 & 0 & 6 & 5 & 1 \\
\hline
\end{tabular}

Table 4: Shows Mean Values of Alanine Aminotransferase (ALT) and Aspartat Aminotransferase (AST) IU/L.

\begin{tabular}{|c|c|c|c|c|c|c|c|c|c|c|c|c|}
\hline \multirow{2}{*}{$\begin{array}{l}\text { Days } \\
\text { Groups }\end{array}$} & \multicolumn{2}{|c|}{ Zero } & \multicolumn{2}{|c|}{$1^{\mathrm{st}}$} & \multicolumn{2}{|c|}{$3^{\text {rd }}$} & \multicolumn{2}{|c|}{$5^{\text {th. }}$} & \multicolumn{2}{|c|}{$7^{\text {th }}$} & \multicolumn{2}{|c|}{$9^{\text {th }}$} \\
\hline & $1^{\mathrm{st}}$ & $2^{\text {nd }}$ & $1^{\mathrm{st}}$ & $2^{\text {nd }}$ & $1^{\mathrm{st}}$ & $2^{\text {nd }}$ & $1^{\mathrm{st}}$ & $2^{\text {nd }}$ & $1^{\mathrm{st}}$ & $2^{\text {nd }}$ & $1^{\mathrm{st}}$ & $2^{\text {nd }}$ \\
\hline \multirow{3}{*}{ ALT } & 62.8 & 69.5 & 63.0 & 70.0 & 62.5 & 69.5 & 63.7 & 68.0 & 61.9 & 69.2 & 59.8 & 65.3 \\
\hline & \pm 3.1 & \pm 3.3 & \pm 2.1 & \pm 2.3 & \pm 1.7 & \pm 2.5 & \pm 3.4 & \pm 2.9 & \pm 1.6 & \pm 2.9 & \pm 2.1 & \pm 2.7 \\
\hline & $\mathrm{bcA}$ & $\mathrm{cA}$ & $\mathrm{bcA}$ & $\mathrm{cA}$ & $\mathrm{bcA}$ & $\mathrm{cA}$ & $\mathrm{Ba}$ & bA & $\mathrm{bcA}$ & $\mathrm{cA}$ & bA & $\mathrm{bA}$ \\
\hline \multirow{3}{*}{ AST } & 115.0 & 124.7 & 191.3 & 193.0 & 187.0 & 192.3 & 143.7 & 140.5 & 114.3 & 125.5 & 114.8 & 124.5 \\
\hline & \pm 5.2 & \pm 3.8 & \pm 7.0 & \pm 7.4 & \pm 5.3 & \pm 8.6 & \pm 5.4 & \pm 5.0 & \pm 4.9 & \pm 3.6 & \pm 4.3 & \pm 2.2 \\
\hline & $\mathrm{abC}$ & $\mathrm{aC}$ & $\mathrm{aA}$ & $\mathrm{aA}$ & $\mathrm{aA}$ & $\mathrm{aA}$ & $\mathrm{aB}$ & $\mathrm{aB}$ & $a b C$ & $\mathrm{aC}$ & $\mathrm{abC}$ & $\mathrm{aC}$ \\
\hline
\end{tabular}

LSD for ALT= 7.5 LSD for AST=13.7, Similar capital letters horizontally denote no differences $\mathrm{P}>0.05$ among periods. Different small letters vertically refers to significant differences $\mathrm{P}<0.05$ between groups.

Table 5: Shows Mean Values of Alkaline Phosphatase (ALP) IU/L.

\begin{tabular}{|c|c|c|c|c|c|c|}
\hline \multirow{2}{*}{ Groups } & \multicolumn{6}{|c|}{ Days } \\
\hline & Zero & $1^{\mathrm{st}}$ & $3^{\text {rd }}$. & $5^{\text {th }}$ & $7^{\text {th }}$ & $9^{\text {th }}$ \\
\hline First & $\begin{array}{c}93.7 \pm 14.0 \\
\text { abA }\end{array}$ & $\begin{array}{c}94.0 \pm 10.9 \\
\text { abA }\end{array}$ & $\begin{array}{c}96.8 \pm 11.0 \\
\text { abA }\end{array}$ & $\begin{array}{c}94.7 \pm 14.1 \\
\text { abA }\end{array}$ & $\begin{array}{c}94.8 \pm 13.1 \\
\text { abA }\end{array}$ & $\begin{array}{c}91.8 \pm 13.8 \\
\text { abA }\end{array}$ \\
\hline Second & $\begin{array}{c}72.3 \pm 8.2 \\
\text { bA }\end{array}$ & $\begin{array}{c}72.2 \pm 8.7 \\
\mathrm{bA}\end{array}$ & $\begin{array}{c}75.8 \pm 9.2 \\
\text { bA }\end{array}$ & $\begin{array}{c}74.8 \pm 7.5 \\
\mathrm{bA}\end{array}$ & $\begin{array}{c}72.7 \pm 7.9 \\
\text { bA }\end{array}$ & $\begin{array}{c}72.5 \pm 8.4 \\
\mathrm{bA}\end{array}$ \\
\hline
\end{tabular}

$\mathrm{LSD}=25.9$, Similar capital letters horizontally denote no differences $\mathrm{P}>0.05$ among periods. Different small letters vertically refers to the existence of significant differences $\mathrm{P}<0.05$ among groups. 
Table 6: Shows Mean Values of Total Serum Bilirubin (TSB) mg/dl.

\begin{tabular}{lcccccc}
\hline \multirow{2}{*}{ Groups } & \multicolumn{7}{c}{ Days } \\
\cline { 2 - 7 } & Zero & $1^{\text {st }}$ & $3^{\text {rd }}$. & $5^{\text {th }}$ & $7^{\text {th }}$ & $9^{\text {th }}$ \\
\hline \multirow{2}{*}{ First } & $0.030 \pm 0.007$ & $0.025 \pm 0.003$ & $0.024 \pm 0.002$ & $0.030 \pm 0.004$ & $0.032 \pm 0.003$ & $0.033 \pm 0.003$ \\
& $\mathrm{aA}$ & $\mathrm{aA}$ & $\mathrm{aA}$ & $\mathrm{aA}$ & $\mathrm{aA}$ & $\mathrm{aA}$ \\
\multirow{2}{*}{ Second } & $0.031 \pm 0.002$ & $0.026 \pm 0.002$ & $0.027 \pm 0.002$ & $0.026 \pm 0.003$ & $0.029 \pm 0.003$ & $0.031 \pm 0.002$ \\
& $\mathrm{aA}$ & $\mathrm{aA}$ & $\mathrm{aA}$ & $\mathrm{aA}$ & $\mathrm{aA}$ & $\mathrm{aA}$ \\
\hline
\end{tabular}

$\mathrm{LSD}=0.007$, Similar capital and small letters horizontally and vertically denote no differences $\mathrm{P}>0.05$ among periods.

Table 7: Shows Mean Values of Total Serum Protein (TSP) g/dl.

\begin{tabular}{lcccccc}
\hline \multirow{2}{*}{ Groups } & \multicolumn{7}{c}{ Days } \\
\cline { 2 - 6 } & Zero & $1^{\text {st }}$ & $3^{\text {rd }}$. & $5^{\text {th }}$ & $7^{\text {th }}$ & $9^{\text {th }}$ \\
\hline \multirow{2}{*}{ First } & $6.50 \pm 0.18$ & $6.10 \pm 0.16$ & $5.70 \pm 0.24$ & $5.75 \pm 0.15$ & $5.60 \pm 0.22$ & $5.80 \pm 0.30$ \\
& $\mathrm{aA}$ & $\mathrm{aA}$ & $\mathrm{aB}$ & $\mathrm{aB}$ & $\mathrm{aB}$ & $\mathrm{aB}$ \\
\multirow{2}{*}{ Second } & $6.85 \pm 0.20$ & $6.31 \pm 0.35$ & $5.60 \pm 40$ & $5.70 \pm 0.30$ & $5.50 \pm 0.20$ & $5.60 \pm 0.13$ \\
& $\mathrm{aA}$ & $\mathrm{aA}$ & $\mathrm{aB}$ & $\mathrm{aB}$ & $\mathrm{aB}$ & $\mathrm{aB}$ \\
\hline
\end{tabular}

$\mathrm{LSD}=0.63$, Similar capital letters horizontally denote no differences $\mathrm{P}>0.05$ among periods. Different small letters vertically refers to significant differences $\mathrm{P}<0.05$ among groups.

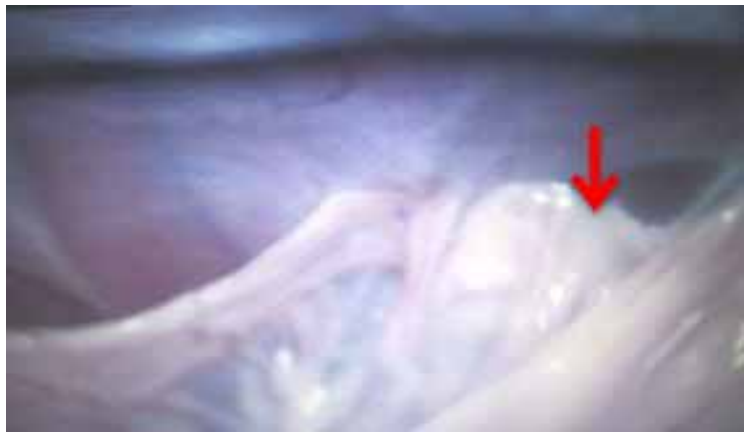

Fig. 8: Laparoscopic veiw shows grade 4 adhesion between Liver and omentum ,abomasums, diaphragm and abdominal wall in the first group (arrow).

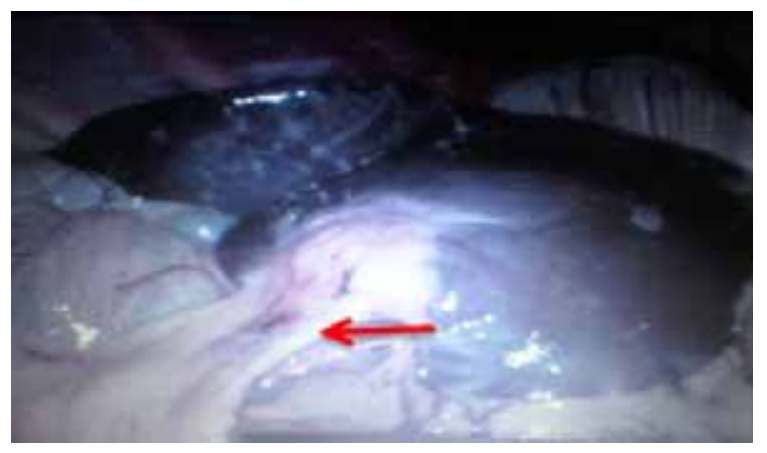

Fig. 9: Laparoscopic veiw shows grade 1 adhesion between liver and omentum (MSAS) in the second group (arrow).

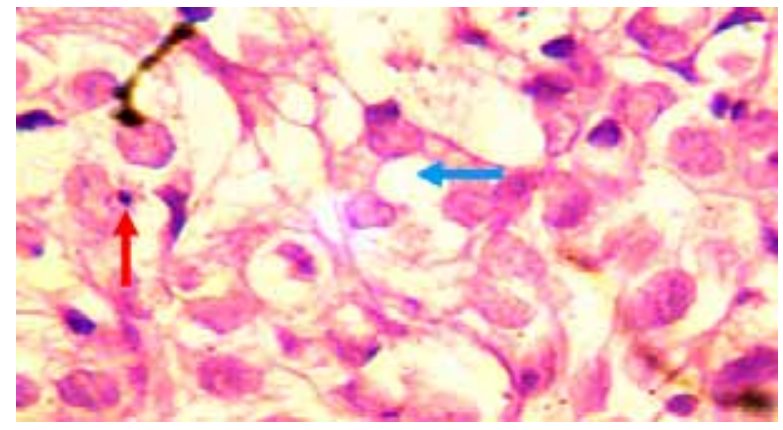

Fig. 10: Histopathological section of liver related to first group, three days postoperation, shows vacuolar degeneration (blue arrow) and atrophy of hepatocytes (red arrow) (H\&E 40X).

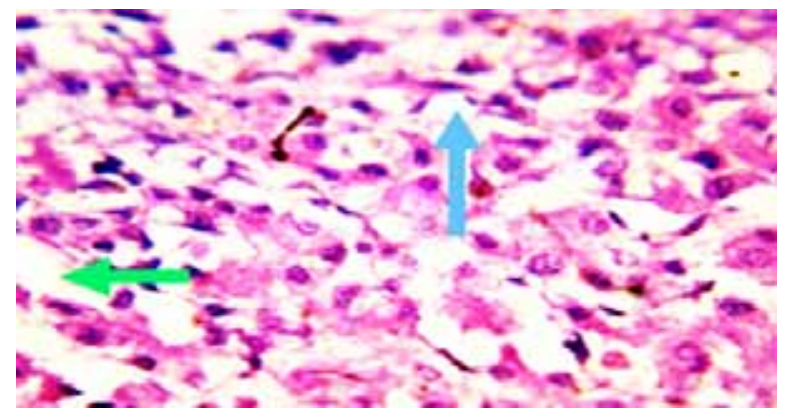

Fig. 11: Histopathological section of liver related to second group, three days postoperation, shows vacoular degeneration of hepatocytes (blue arrow) with dilated sinusoid (green arrow) (H\&E 40X) . 


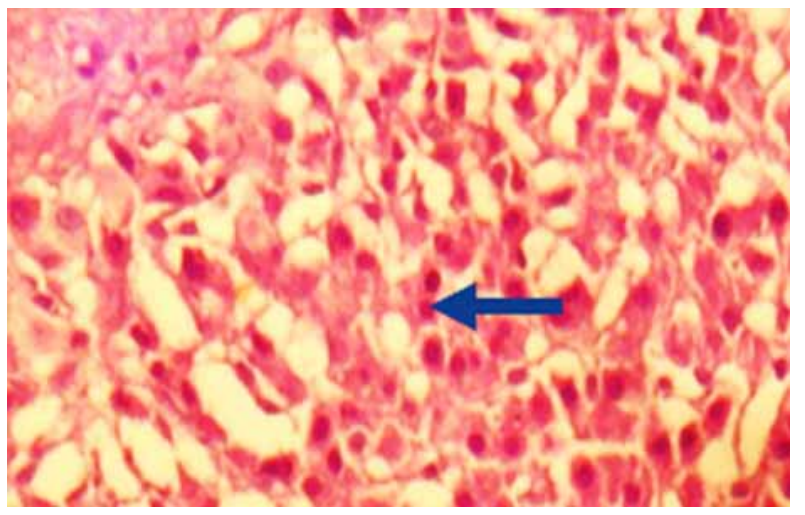

Fig. 12: Histopathological section of liver related to first group, seven days postoperation, shows mild regeneration of hepatocytes (arrow) (H\&E 40X) .

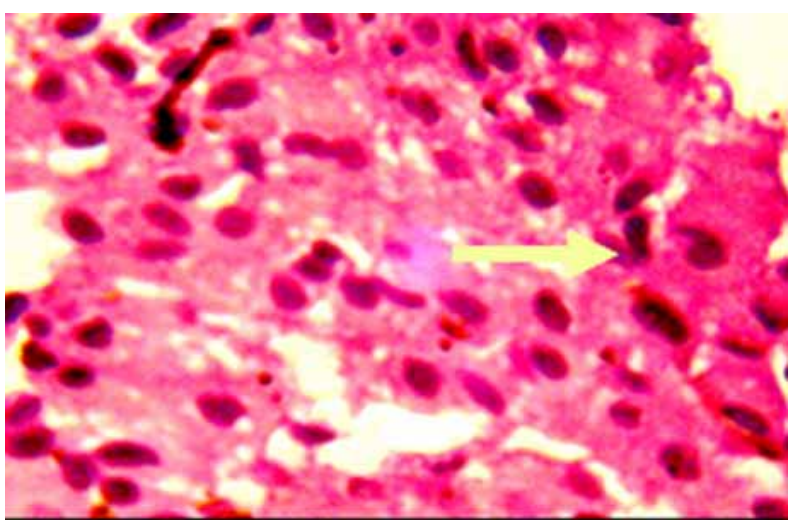

Fig. 13: Histopathological section of liver related to second group, seven days postoperation, shows extensive regenerative activity in hepatocytes adjacent to the resected area (arrow) (H\&E 40X).

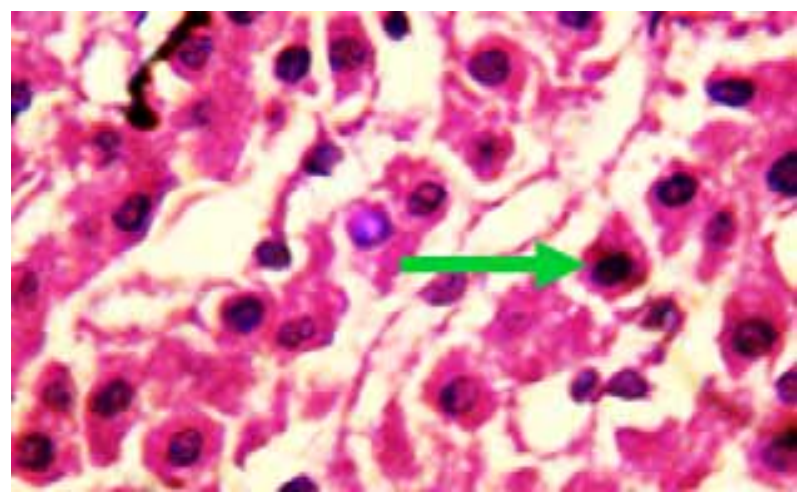

Fig. 14: Histopathological section of liver related to first group, fifteen days postoperation, shows hepatocytes adjacent to the resected area and mild regenerative activity (arrow) (H\&E 40X).

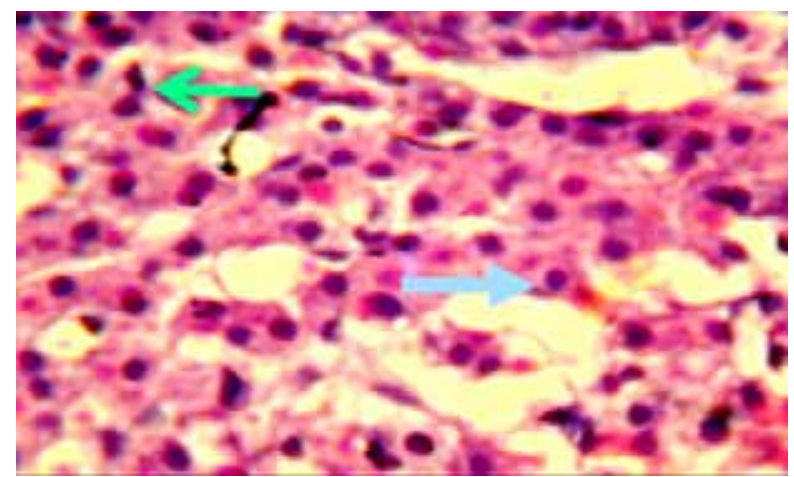

Fig. 15: Histopathological section of liver related to second group, fifteen days postoperation, shows hepatocytes in area far away from resected part with dark basophilic nuclei (blue arrow), some cells have more nuclei with mitosis (green arrow) (H \& E 40X).

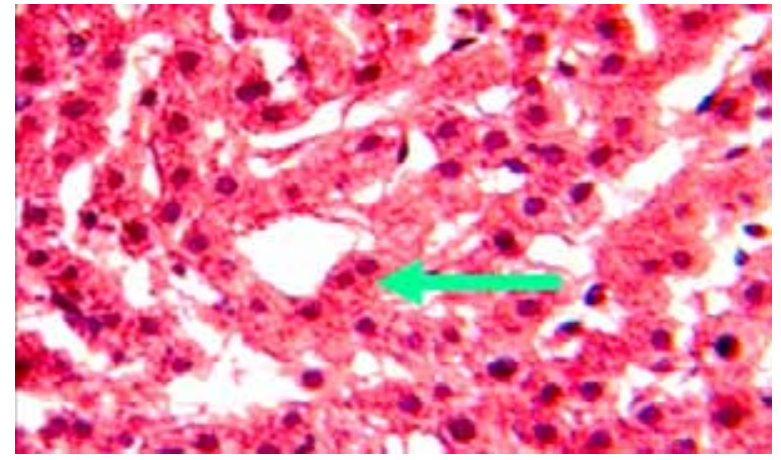

Fig. 16: Histopathological section of liver related to first group, four months postoperation, liver returned to the normal structure which consist from hepatocytes cord around the central vein (arrow) (H\&E 40X).

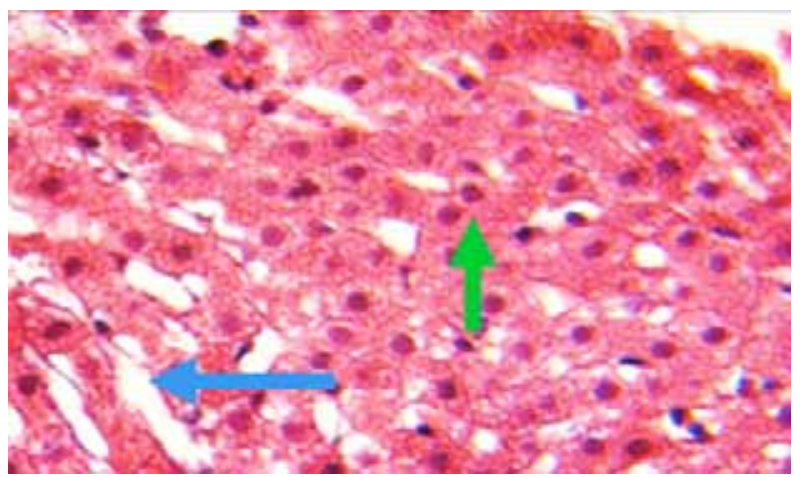

Fig. 17: Histopathological section of liver related to second group, four months postoperation, shows normal hepatic architecture which represented by normal lobules, central vein (green arrow) and sinusoids (blue arrow) (H\&E40X). 


\section{Discussion}

The clinical parameters were within normal level, this findings agreed with other workers (10 and 11), whom mentioned that there were no significant changes recorded in these clinical parameters before and after laparoscopic cholecystectomy in dogs and goats respectively. The animal activity and appetite were not altered, with few exception in the activity. This may be attributed to visceral pain or adhesions formation. Similar interpretion was reported by previous researches (12).

The clamp was minimized the operative and resection times, in this technique resection can be performed under a modified liver clamp without needed time for liver mobilization, control of inflow and out flow of liver vessels.. These advantages also reported by some authors (13 and 14). There are many factors that may be affects the operative and resection times which includes surgeon training and experience in laparoscopic liver surgery. This result agreed with previous studies (11 and 15).

Intraoperative complications, mainly bleeding control, suctioned and cleared the operative field required relatively longer time and that result also reported by (16). Laparoscopy may be contributed to decrease the operative time and reduce preoperative blood loss this lead to diminish surgical stress because of development of device, improvement of procedure and advanced techniques (17). Wedge resection is not so problematic as regards bleeding, due to improvements in hemeostatic devices such as the ultrasonic dissector for small vein or biliary elements (18). Several workers reported that the clamp- crushing technique had lowest blood loss compared with other dissecting sealer devices and proved to be also the most cost-efficient technique (19). When $20 \%$ of blood is lost from the total blood volume of the body, the circulatory system function not affected because there are many blood reservoir, like venous blood system, liver and spleen (20). There was no bile leakage, this result supported by the absence of the significant increased of TSB between both groups in present study. The adhesion of omentum to the resected line of the liver (raw surface) on the $3^{\text {rd }}, 7^{\text {th }}$, and $15^{\text {th }}$ days postoperatively prevent the bile leakage, this supported by (21), whom reported that suturing of omentum into the defected liver, prevent bile leakage. The hassel such as bleeding during laparoscopic liver surgery can enhance adhesion formation (22). Ultrasonically activated device may divide both vessels and bile ducts, with no need of further ligature, and possibly reduce the risk of thermal injuries and bile duct injuries and the lateral energy spread are minimal and the risk of distant tissue damage is lower than of high frequency electro- surgery (23).

The significant increased of ALT mean values in the second group may be attributed to elevation in normal value of ALT preoperatively in animals related to this group.
Laparoscopic surgery lead to transient elevations of ALT and AST enzymes, these elevations are self-limited and not associated with any morbidity in patient with normal liver function (24). These enzymes elevations may be ascribed to the negative effects of the pneumoperitoneum on the hepatic blood flow (25). Also alterations in the microcirculation, cellular hypoxia and then affecting cells membrane and liberate enzymes (26). In addition studies in dogs and goats by (10 and 11) respectively, showed no significant differences in ALT, AST and ALP levels postoperatively. AST is present in most tissue and increases with muscle injury especially cardiac muscle, as well as hepatocellular injury, also present in kidney, pancreas and erythrocytes. Thus AST assays should be run in conjunction with other enzymes assay, especially ALT when evaluating liver function. Increased ALT with normal to mild elevation in AST value may indicate reversible liver damage. Marked elevation in ALT and AST indicate hepatocellular necrosis. Increased AST with normal ALT may indicate that the source of AST is not liver (27). Serum ALP activity usually increased in animals with biliary stasis, steroid hepatopathy and occasionally bone lesions. In addition ALP is found in much tissue, including liver, bone, intestine, placenta and kidneys (28).

In cattle, most hyperbilirubinemia is caused by hemolysis, and even in severe liver diseases in cattle, sheep, goat and pig, only slight increases in TSB was noted (27). The decrement in TSP refers to hypoalbuminemia resulting from hepatocellular injury thus protein synthesis may be reduced, however this may not be evident immediately because the proteins half-live is relatively longer compared to half-live of enzymes (29).

The results of histopathological examinations between two groups on three days post- operation showed that the second group, had less pathological findings, and the hepatocytes adjacent to the resected area showed mild pathological changes, also early and extensive regeneration of hepatocytes at days seven and fifteen in second group was faster than first groups. This results indicated that ultrasurgical technique had less effect than clamp crush, this outcome supported with many researches that reported the lower maximal temperature achieved with the harmonic scalpel (below $80^{\circ} \mathrm{C}$ ), result in a reduce tissue charring and desiccation, also minimizes the zone of thermal destruction, this minimal thermal damage may explain the marked reduction in post operative adhesions to the liver bed injuries. This observation was described by other workers (23 and 30). Fibroblasts produce collagen fibers and angioblasts form capillary blood vessels to form granulation tissue and the degree of granulation tissue depend on degree of tissue destruction. The presence of myofibroblasts in granulation tissue which originated from mature fibroblasts, refers to severe destruction and these cells attempt to contract the affected area due to their function which 
resemble smooth muscle cells. This phenomina was agreed with (20). In present study the liver regeneration appeared early and extensive in second group comparing to first group, this is due to little hepatic damage and necrosis during ultrasurgical technique.This findings coincide with others (31), whom said that the liver regeneration occurred rapidly after resection of the right lobe of the liver in humans. Also (32), in their study on the normal human liver found that mitosis appear at 10 and 35 days and the histopathological findings were cells with basophilic cytoplasm or two nuclei and the liver remnant was morphologically normal at four months postsurgery. In conclusion ultrasurgical technique is the best in comparing with clamp crush for laparoscopic partial hepatoectomy in rams.

\section{References}

1. Morris KT, Song TJ and Fog Y. Recent advancements in diagnosis and treatment of metastatic colo-rectal cancer to the liver. Surg. Oncol. 2006 ; 15: 129 -137.

2. Jackman SV, Cadeddu, JA and Chen R.N. Vtility of the harmoic scalpel for laparoscopic partial nephrectomy. J. Endourol. 1998 ; 12:441- 446.

3. Perk C, Mutlu Z, Gürel A, and Haktanir D. Comparison of Electrocautery and Quantum Energy Surgical Devices in Experimental patial Hepatectomies. Turk. J. Vet. Anim. Sci. 2006 ; 30:77-82.

4. Hikasa Y, hokushin S Takase K and Ogasawara S Cardiopulmonary, hematological, serum biochemical and behavioral effects of sevoflurane compared with isoflurane or halothane in spontaneously vetilating goats. Small Rumin. Res. 2002 ; 43, Issue 2:167-178.

5. Taylor P. Anesthesia in sheep and goats. Practice. 1991; 91:31-36.

6. Ghahiri AA, Zareen A, Rasti M, and Adibi S. Effect of Dpenicillamine in prevention of post operative pelvic adhesion formation in rat. J. R. M. S. 2006 ; 11(5): 313-318.

7. Greene AK, Alwayn IP, Nose V, Flynn E, Sampson D, and Zurakowski D. Prevention of intra-abdominal adhesions using the antiangiogenic COX-2 inhibitor celecoxib. Ann. Surg. 2005 ; 242(1): 140-146.

8. Prophet EB, Mills B, and Arrington JB. Laboratory methods in histotechnology. Washington: Armed Forces Institute of Pathology; $1992: 275$ P.

9. SAS, 2001. Statistical Analysis System for Windows ; $2006: 6: 12$.

10. Al-Badrany MS. Cholecystectomy and liver biopsy achievement by laparoscopy in dogs. Ph.D. Thesis. College of Veterinary MedicineMosul University- Mosul- Iraq; 2006.

11. Alkhilani MA. A comparative Study between Complete and Subtotal Laparoscopic Cholecystectomy in Goats in induced Cholecystitis, Ph.D. Thesis, Vet Medicine/ Baghdad University. Baghdad- Iraq; 2010.

12. Nakajima J, Sasaki A, Toru-obuchi, T Baba S, Nittaand $\mathrm{H}$ and Wakabayashi C Laparoscopic Subtotal Cholecystactomy for severe Cholecystitis Surg. Today. (2009) ; 39(10):870-875.
13. Descottes B, Lachachi F and Sodji M. Early experience with laparoscopic approach for solid liver tumors: initial 16 cases. Ann. Surg. $2000 ; 232$ (5): 641-645.

14. Gigot JF, Glineur D, and Santiago AJ.Laparoscopic liver resection for malignant tumors: preliminary result of a multicenter European study. Am. Surg. $2002 ; 236: 90-97$.

15. Cadière GB, Torres R, Dapri G, Capelluto E, and Himpens J. Laparoscopic left lateral hepatic lobectomy for metastatic colorectal tumor. Surg. Endosc. 2005 ; 19(1):152-161.

16. Bull J F, Thomas M J, Doty T C, Gersin K S, Merchen T D, Gupta M, Rudich S M and Woodle E S.An initial experience and evolution of laparoscopic hepatic resectional surgery. Surgery; 2004 ; 136:804-811.

17. Ueda K, Turner $P$ and Gagner M. Stress response to laparoscopic liver resection. HPB. 2004 ; 6(4):247-252.

18. Ryam JA and Jaulkner D J. Liver resection without blood transfusion. Am. J. Surg. 1989 ; 157: 472-475.

19. Gurusamy KS, Pamecha V, Sharma D and Davidson BR.Techniques for liver parenchymal transection in liver resection. Cochrane Database of systemic Review. Issue (1) 2009.

20. Cullen JM and Maclachlan NJ. Liver, biliary system and exocrine pancreas. In: Carlton, WW. and Zachary, JF. Thomson's Special Veterinary Pathology. $3^{\text {rd }}$ ed. Mosby; Chapter (2) $2001: 81 \mathrm{P}$

21. Spencer L, Metcalfe M S, Strickland A D, Elsey E J, Robertson G S and Lloyd D M. Lessons from Laparoscopic Liver Surgery: A NineYear Case Series. HPB Surg. (2008).

22. Baakdah $\mathrm{H}$ and Tulandi T. Adhesion in gynecology. Complication, cost, and prevention.Surg. Technol. Int. $2005 ; 14: 185-189$.

23. Amaral J F and Chrostek C. Comparison of the ultrasonically activated scalpel to electrosurgery and laser for laparoscopic surgery. Min. Inva. Ther. And Allied Technol. 1997 ; 6: 324-331.

24. Hasukic S. Postoperative changes in liver function tests: randomized comparison of low and high-pressure laparoscopic cholecystectomy. Surg. Endosc. 2005 ; 19: 1451-1455.

25. Güven HE and Oral S. Liver enzyme alternations after laparoscopic cholecystectomy. J. Gastrointestinal Liver Dis. 2007 ; 16 (4): 391- 394.

26. Marakis G, Pavlidis TE, Ballas K, Rafailidis S and Psarras K. Alternations in liver function tests following laparoscopic cholecystectomy. Internet. J. Surgery; 2006 ; 8(1); 216-221.

27. Tighe, MM. and Brown, H. Clinical Chemistry. In: Mosby's Comprehensive Review for Veterinary Technicians. $2^{\text {nd }}$ ed., Chapter (6) 2003 ; 98- 99 P.

28. Tilley L P and Smith F W. The 5 minute veterinary consult canine and feline. Williams and Wilkins. 1997; P:182.

29. Evans GO. Animal Clinical Chemistry: A practical Guide for Toxicologist and Biomedical Researcher. $2^{\text {nd }}$ ed. Taylor and Francis Group, Boca Raton, London, New York; 2009; 153-159 p.

30. Meltzer RC, Hoenig DM, Chrostek, C and Amaral JF. Porcine seromyotomies using an ultrasonically activated scalpel. Surg. Endosc. 1994; $8: 250-253$.

31.Zappa M, Dondero F, Sibert A, Vullierme M, Belghiti J and Vilgrain V. Liver regeneration at day 7 after right hepatectomy global and segmental volumetric analysis by using CT.RSNA. 2009; (2)73-81.

32. Nagasue N, Yukaya H, Ogawa Y Kohno H and Nakamura T. Human liver regeneration after major hepatic resection: A study of normal liver with chronic hepatic and cirrhosis. Ann. Surg. 1987 ; (1): 206- 211. 